\title{
Immunosuppressive Effects of Multipotent Mesenchymal Stromal Cells on Graft-Versus-Host Disease in Rats Following Allogeneic Bone Marrow Transplantation
} Ratlarda Kemik İliği Nakli sonrası gelişen Graft Versus Host Hastalı̆̆ıda Multipotent Mezenşimal Stromal Hücrelerin İmmünsupresif Etkileri

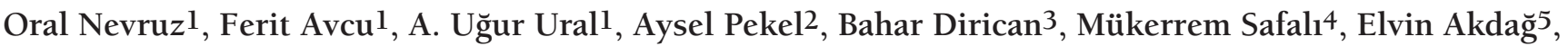
Murat Beyzadeoğlu3 , Tayfun İde ${ }^{5}$, Ali Sengül2

${ }^{1}$ Gülhane Medical Academy, Department of Hematology, Ankara, Turkey

${ }^{2}$ Gülhane Medical Academy, Department of Immunology, Ankara, Turkey

${ }^{3}$ Gülhane Medical Academy, Department of Radiation Oncology, Ankara, Turkey

${ }^{4}$ Gülhane Medical Academy, Department of Pathology, Ankara, Turkey

${ }^{5}$ Gülhane Medical Academy, Department of Medical Oncology Research Center, Ankara, Turkey

\begin{abstract}
:
Objective: Graft-versus-host disease (GVHD) is a major obstacle to successful allogeneic bone marrow transplantation (allo-BMT). While multipotent mesenchymal stromal cells (MSCs) demonstrate alloresponse in vitro and in vivo, they also have clinical applications toward prevention or treatment of GVHD. The aim of this study was to investigate the ability of MSCs to prevent or treat GVHD in a rat BMT model.

Materials and Methods: The GVHD model was established by transplantation of Sprague Dawley rats' bone marrow and spleen cells into lethally irradiated ( $950 \mathrm{cGy}$ ) SDxWistar rat recipients. A total of 49 rats were randomly assigned to 4 study and 3 control groups administered different GVHD prophylactic regimens including MSCs. After transplantation, clinical GVHD scores and survival status were monitored.

Results: All irradiated and untreated control mice with GVHD died. MSCs inhibited lethal GVHD as efficiently as the standard GVHD prophylactic regimen. The gross and histopathological findings of GVHD and the ratio of CD4/CD8 expression decreased. The subgroup given MSCs displayed higher in vivo proportions of CD25+ T cells and plasma interleukin-2 levels as compared to conventional GVHD treatment after allo-BMT.

Conclusion: Our results suggest that clinical use of MSCs in both prophylaxis against and treatment of established GVHD is effective. This study supports the use of MSCs in the prophylaxis and treatment of GVHD after allo-BMT; however, large scale studies are needed.
\end{abstract}

Key Words: Mezenchimal stromal cell, Bone Marrow Transplantation, İmmunsupresion

Address for Correspondence: Oral NEVRUZ, MD

Gülhane Medical Academy, Department of Hematology, Ankara, Turkey

Phone: +90 3123044104 E-mail: onevruz@hotmail.com 


\section{Özet:}

Amaç: Graft versus host hastalığı (GVHH) , başarılı bir kemik iliği nakli için önemli bir engel oluşturmaktadır. Multipotent mezenşimal stromal hücrelerin (MSH) immünsupresif etkileri, in vivo ve in vitro olarak gösterilmiş olmakla birlikte, GVHH' nı önleme yönünde klinik uygulamalarda bulunmaktadır .

Gereç ve Yöntemler: Bu çalışmanın amacı ratlarda kemik iliği nakli sonrası oluşturulan GVHH'nı önleme ve tedavi etmede MSH nin etkinliğinin incelenmesidir. Bu amaçla 49 Sprague Dawley cinsi rat rastegele 4 çalışma, 3 kontrol grubuna ayrılmış ve gruplara MSH de içeren farklı GVHH önleyici tedaviler uygulanmıştır. Kemik iliği nakli sonrası GVHH skorlaması ve yaşama süreleri incelenmiştir.

Bulgular: Tüm ışınlanmış ve önleyici tedavi verilmemiş ratlar ölmüştür. MSH nin önleyici uygulamaları, standart GVHD önleyici tedavileri kadar etkin bulunmuştur. MSH uygulamaları, GVHH nın gözlemsel ve histolojik bulgularını ve CD4+/CD8+ oranını azaltmaktadır.Ayrıca MSH uygulanan gruplarda CD25+ T hücrelerinin in vivo oranıda daha yüksek olup, Allojeneik kemik iliği nakli sonrası standart GVHH tedavisi uygulananlara göre plazma İnterlökin-2 seviyesinin daha yüksek olarak saptanmıştır.

Sonuç: Bulgularımız MSH uygulamasının, GVHH nın hem önlenme hem de tedavi edilmesinde etkin olduğunu göstermiştir. Ancak bu bulguların geniş ölçekli çalışmalarla desteklenmesi gerekmektedir.

Anahtar Sözcükler: Mezenkimal stromal hücre, Kemik iliği nakli, İmmünspresyon

\section{Introduction}

Allogeneic hematopoietic stem cell transplantation (alloHSCT) after high-dose marrow-ablative chemoradiotherapy is an effective treatment method in various hematologic, neoplastic, and congenital disorders. The major complication after allo-HSCT is the development of graft-versus-host disease (GVHD). GVHD is a life-threatening complication even when the major histocompatibility complex is matched $[1,2]$. Immunosuppressive therapy (i.e. cyclosporine and/ or steroids) is still the first-line treatment for established GVHD; however, the outcome for patients with steroidresistant acute GVHD is poor, as is overall survival [3].

Multipotent mesenchymal stromal cells (MSCs) are multipotent progenitor cells that can differentiate along multiple mesenchymal lineages including bone, cartilage, or fat and expand extensively in vitro $[4,5]$. The interest in MSC therapy has been raised by the observation that MSCs are able to modulate immune responses in vitro and in vivo [6]. MSCs display immunosuppressive properties that suppress the proliferation of $\mathrm{T}$ cells induced by alloantigens or mitogens [7]. Furthermore, MSCs have been reported to induce $\mathrm{T}$ cell division arrest, to inhibit the differentiation and maturation of dendritic cells, and to decrease the production of inflammatory cytokines by various immune cell populations $[8,9,10]$. These properties can be utilized in the context of allo-HSCT, particularly to modulate GVHD and graft rejection [6]. Therefore, MSCs can be thought of as promising agents for severe steroid-resistant acute GVHD and nonresponders can be treated with alternative methods, including MSCs (11)

The aim of this study was to evaluate the prophylactic and therapeutic potential of MSCs against GVHD using an established rat model of acute GVHD.

\section{Materials and Methods}

Animals

Female Wistar rats of 10-12 weeks old were used as recipients and male Sprague Dawley (SD) rats as donors. All procedures were performed according to the institutional guide for animal experimentation and the study protocol was approved by the institutional ethics committee.

Bone Marrow Preparation and Bone Marrow-Derived

Rat MSC Generation

Briefly, SD rats were sacrificed by decapitation and bone marrow (BM) was flushed with L-DMEM (Gibco, Grand Island, NY, USA) using a 23-gauge needle from femurs and tibias. The BM cells were then pelleted by centrifugation at $1000 \mathrm{rpm}$ for $15 \mathrm{~min}$. The BM cells were gently resuspended using an 18-gauge needle and filtered through a sterile nylon mesh. The viability was consistently $>95 \%$ as determined by trypan blue exclusion.

For the MSC generation, BM cells were plated in 25$\mathrm{cm}^{2}$ polystyrene flasks in L-DMEM supplemented with $10 \%$ fetal bovine serum at $37{ }^{\circ} \mathrm{C}$ with $5 \% \mathrm{CO} 2$ conditions (Gibco). Cells were allowed to adhere for $72 \mathrm{~h}$ followed by the removal of nonadherent cells and media were changed every 3 to 4 days. Adherent cells were detached using trypsin-EDTA solution-B (EDTA $0.05 \%$, trypsin $0.25 \%$, with phenol red; Biological Industries, Beit-Haemek, Israel) at $37{ }^{\circ} \mathrm{C}$ for $10 \mathrm{~min}$ and MSCs were expanded 3-4 times to achieve the desired cell numbers for use in in vitro and in vivo experiments.

Preparation of Viable Splenocytes

SD rats weighing between 200 and $250 \mathrm{~g}$ were sacrificed by decapitation to be used as donors for splenocytes. After sterile splenectomy, spleens were collected and kept on ice with L-DMEM (Gibco) supplemented with penicillin (100 U/mL) 
and streptomycin $(100 \mu \mathrm{g} / \mathrm{mL})$. The spleens were disrupted in the medium by pressing spleen fragments between 2 glass slides. Spleen cell suspensions were filtered through a 100mesh nylon filter and washed 3 times with L-DMEM medium. Splenocyte viability was consistently $>95 \%$ as determined by trypan blue exclusion. Viable nucleated cells were counted and adjusted to $4.0 \times 108 / 500 \mu \mathrm{L}$.

\section{Allo-HSCT Procedure}

We generated a rat GVHD model in the context of alloHSCT with infusion of 4x108 donor splenocytes. Allo-HSCT was performed with isolation of $1 \times 108$ mononuclear cells from male SD rat donors, dilution in $0.5 \mathrm{~mL}$ of phosphatebuffered saline, and infusion to female Wistar rat recipients via the tail veins. The recipient animals were conditioned with a myeloablative regimen consisting of $950 \mathrm{cGy}$ of total body irradiation prior to allo-HSCT. The GVHD prophylactic regimen was arranged as $3 \mathrm{mg} / \mathrm{kg} /$ day cyclosporine-A (CsA) and $0.25 \mathrm{mg} / \mathrm{kg}$ methotrexate (MTX) intraperitoneally at days $+1,+3$, and +6 .

\section{Experimental Design}

A total of 49 Wistar rats were enrolled in this study and they were randomly assigned to 4 study groups (SGs) and 3 control groups (CGs) ( $n=7$ each). The GVHD model was generated in all SGs but only in one CG.

1. CG-I: Allo-HSCT and GVHD (enforced through donor splenocyte infusion).

2. CG-II: No allo-HSCT, myeloablative regimen only (total body irradiation).
3. CG-III: No allo-HSCT, no myeloablative regimen (no GVHD).

4. SG-I: Allo-HSCT, only standard GVHD prophylactic regimen (CsA+MTX) on day -1 of allo-HSCT.

5. SG-II: Allo-HSCT, given only MSCs ( $2 \times 10^{6}$ cells $/ \mathrm{kg}$ ) on day +1 after allo-HSCT.

6. SG-III: Allo-HSCT, given standard GVHD prophylactic regimen on day -1 of allo-HSCT plus MSCs (2x106 cells $/ \mathrm{kg}$ ) on day +1 of allo-HSCT.

7. SG-IV: Allo-HSCT, given MSCs (2x106 cells $/ \mathrm{kg})$ after observation of GVHD findings.

The rats were observed daily for clinical signs of GVHD, such as diffuse erythematous lesions (particularly of the ears and extremities), hyperkeratosis of the footpads, skin rash, diarrhea, anorexia, and weight loss (Figure 1). Immunophenotypical (CD4, CD8, CD25, and plasma IL-2 levels) examinations and histopathological findings of GVHD (Table 1; Figure 2) following allo-HSCT were performed, and the survival of all groups was monitored.

\section{Statistical Analysis}

To evaluate the effects of several variables on overall survival, Kaplan-Meier survival analysis (log-rank statistics) was performed. Differences among the treatment groups were assessed by nonparametric Mann-Whitney U tests. Analyses were managed with SPSS 10.0 (SPSS Inc., Chicago, IL, USA) and the significance level was 5\% ( $<<0.05)$.

Table 1. GVHD-related pathological findings of groups

\begin{tabular}{|c|c|c|c|c|c|}
\hline Groups & Hepatic & $(\%)$ & \multicolumn{2}{|c|}{ Intestinal (n) } & Dermatological (n) \\
\hline CsA+MTX & Mild portal inflammation & $(42.9)$ & $\begin{array}{l}\text { Cryptitis } \\
\text { G I } \\
\text { G II } \\
\text { G III }\end{array}$ & $\begin{array}{l}(2) \\
(2) \\
(1)\end{array}$ & $\begin{array}{l}\text { G I: Focal/diffuse vacuolization of } \\
\text { basal layer (3) }\end{array}$ \\
\hline MSC & Mild portal inflammation & $(28.6)$ & $\begin{array}{l}\text { Cryptitis } \\
\text { G I } \\
\text { G II }\end{array}$ & $\begin{array}{l}(1) \\
(2)\end{array}$ & $\begin{array}{l}\text { G I: Focal/diffuse vacuolization of } \\
\text { basal layer (3) }\end{array}$ \\
\hline BMT-CONTROL & $\begin{array}{l}\text { Damage of bile duct } \\
\text { Cytoplasmic vacuolization } \\
\text { Necrosis of hepatocytes } \\
\text { Periportal inflammation }\end{array}$ & $\begin{array}{l}(28.6) \\
(42.9) \\
(14.3) \\
(57.2)\end{array}$ & $\begin{array}{l}\text { Cryptitis } \\
\text { G I } \\
\text { G II } \\
\text { G III } \\
\text { G IV }\end{array}$ & $\begin{array}{l}(1) \\
(2) \\
(3) \\
(1)\end{array}$ & $\begin{array}{l}\text { G I: Focal/diffuse vacuolization of } \\
\text { basal-layer (4) } \\
\text { G II: Spongiose+dyskeratotic } \\
\text { keratinocyte, lymphocytes } \\
\text { infiltration ( } 3 \text { ) } \\
\text { G III: Subepidermal separation (1) }\end{array}$ \\
\hline
\end{tabular}


70

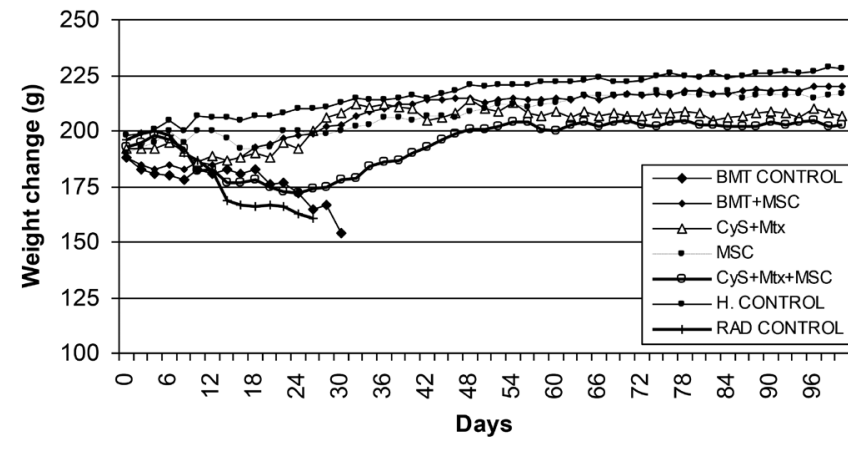

Figure 1. The weight changes of the study and control group rats during the experiment.

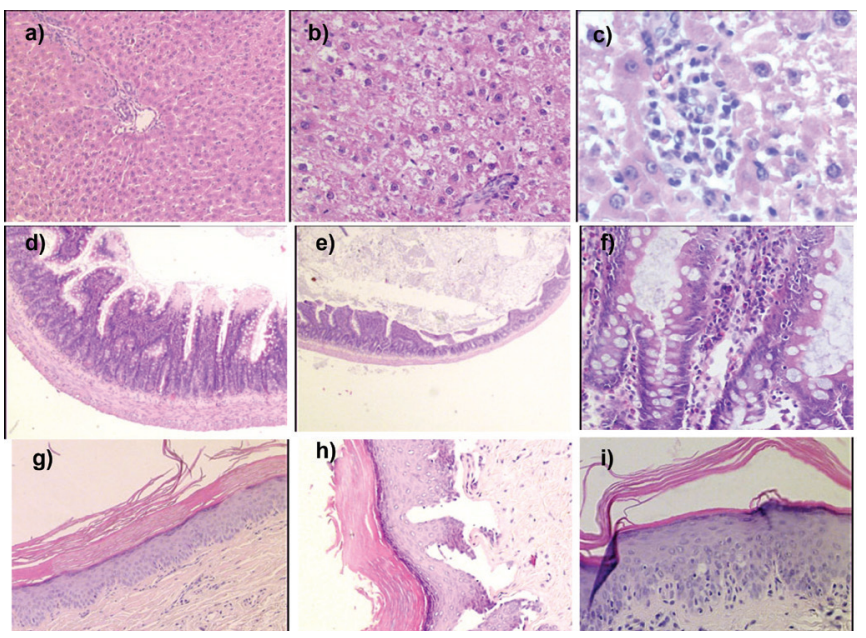

Figure 2. GVHD-related histopathological examination of groups. a, b, c: Hepatic pathology of GVHD (a: healthy control, 50x; b: BMT-control-GVHD, 100x; c: BMT-controlGVHD, 200x). d, e, f: Intestinal pathology of GVHD (d: healthy control, 50x; e: BMT-control-GVHD, 25x; f: BMTcontrol-GVHD, 200x); g, h, i: Dermatological pathology of GVHD (g: healthy control, 50x; h: BMT-control-GVHD, 100x; i: BMT-control-GVHD, 200x).

\section{Results}

Wistar recipients from male SD donors were transplanted with allogeneic hematopoietic stem cells (allo-HSC) or MSCs as described above. The survival of the Wistar rats as shown in the Kaplan-Meier survival curve following allo-HSCT (Figure 3) was significantly longer in SG-I, SG-II, and SG-IV than in CG-I $(p<0.05)$. However, the survival of SG-III was not significantly longer than in CG-I. The semiquantitative clinical scoring scale showed significant differences of the severity of GVHD (Figure 4). Clinical signs and symptoms of GVHD were significantly lower in SG-I and SG-II than in CG-I ( $p<0.05$ and $p<0.05$, respectively). However, SGIII and SG-IV were not significantly different from CG-I ( $p>0.05$ and $p>0.05$, respectively).

Statistical evaluation was performed on day 28. Immunophenotypical (CD45, CD4, CD8, and CD25) examinations and plasma IL-2 levels were performed for

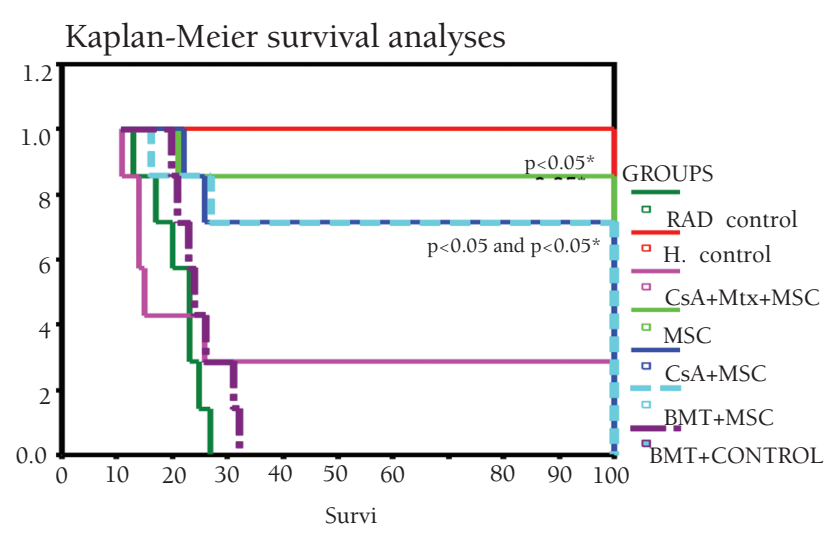

Figure 3. Kaplan-Meier survival curves of the study and control group rats (*: statistical significance in comparison with BMT-control).

all groups following allo-HSCT. The expression of CD25 increased significantly $(\mathrm{p}<0.001)$ in all SGs and CG-I compared to CG-III. Intergroup comparisons of all SGs and CG-I in terms of CD25 expression were not statistically significant (Figure 5). The ratio of CD4/CD8 expression was significantly lower in SG-I ( $\mathrm{p}=0.008)$ than in CG-III. In contrast, this expression was significantly higher in SG-II and SG-IV ( $\mathrm{p}=0.014$ for both) compared to CG-III (Figure 6). Plasma IL-2 levels were significantly increased in SG-I $(\mathrm{p}=0.032)$, SG-II $(\mathrm{p}=0.018)$, and SG-IV $(\mathrm{p}=0.032)$ compared to CG-I. This increase was much more prominent $(\mathrm{p}<0.001)$ in CG-I than in CG-III (Figure 7).

\section{Discussion}

Allo-HSCT is an increasingly used treatment modality for hematological malignancies [2]. However, GVHD is a life-threatening complication of allo-HSCT caused by donor lymphocytes reacting against host tissues and is a major contributor to morbidity and mortality associated with this procedure $[1,12]$. Several studies have suggested that MSCs could exert immunomodulatory properties to reduce the incidence of GVHD after allo-HSCT. GVHD can be readily controlled by escalation of systemic immunosuppression (prophylactic regimens or systemic high-dose steroids) in up to $70 \%$ of patients $[13,14]$. However, patients whose GVHD is refractory to this therapy have a poor prognosis. There is no standard second-line or salvage therapy for these patients and various therapeutic modalities have been administered. However, the results so far have demonstrated limited efficacy and low long-term survival due to toxicity $[15,16,17,18,19]$.

Administration of MSCs is an alternative option in the treatment of steroid-refractory GVHD. Immunomodulatory properties of MSCs have been exploited to reduce the incidence of GVHD after allo-HSCT [10,11,21,22,23,24,25]. First, the effectiveness of MSCs on GVHD was supported by in vitro studies. Ning et al. first reported the effectiveness of human BM MSCs on allogeneic T lymphocyte phenotype in vitro (26). In vivo studies have also supported the effectiveness 


\begin{tabular}{|l|l|l|l|l|l|}
\hline a) Diarrhea & \multicolumn{2}{c|}{ Alopecia } & \multicolumn{2}{c|}{ Weight loss } \\
\hline No & 0 & No & 0 & No & 0 \\
\hline Yes & 1 & Yes & 1 & yes & 1 \\
\hline Severe & 2 & Severe & 2 & & \\
\hline
\end{tabular}

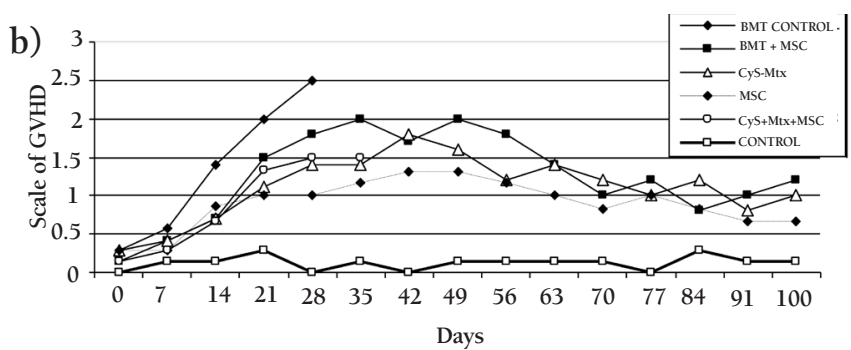

Figure 4. a) Evaluation of the severity of GVHD with the semiquantitative clinical scoring scale utilizing diarrhea, alopecia, and weight changes over the experiment period; b) degree of GVHD in the study and control group rats.

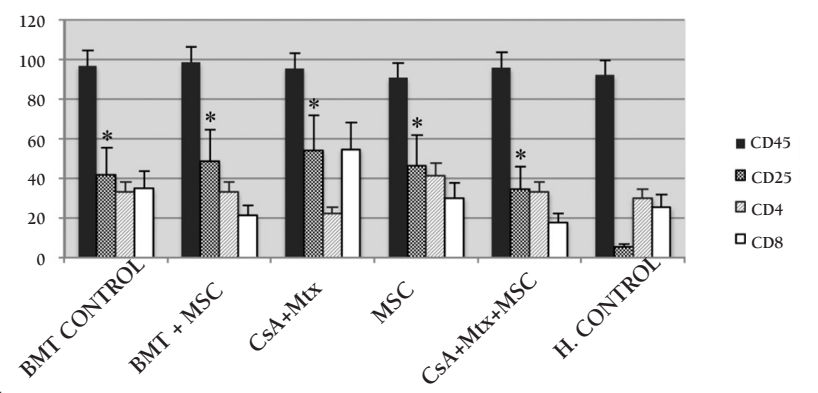

Figure 5. Results of immunophenotypical analyses (CD45, CD4, CD8, CD25) in the study and control groups: CD25 was significantly increased $(\mathrm{p}<0.001)$ in all study groups and was higher in CG-I than in CG-III.

*: $\mathrm{p}<0.001$ in comparison with healthy control (SG-I).

can prevent lethal GVHD following allo-HSCT by means of homeostasis of $\mathrm{T}$ lymphocyte subsets in vivo. Their study demonstrated that the value of CD8+ and CD4+ T cells and the ratio of Th1/Th2 $\mathrm{T}$ cell subsets decreased at the same time, so the proportion of CD4+, CD25+ T cells increased both in spleen lymphocytes and thymocytes in vivo after allo-HSCT with MSC co-transplantation [27]. Our results, too, suggest that BM-derived MSCs can prevent GVHD after allo-HSCT by means of homeostasis of $\mathrm{T}$ subsets in vivo. We also report a decreased ratio of CD4/CD8 expression, along with an increased proportion of CD25+ T cells and plasma interleukin-2 levels in vivo after allo-HSCT with prophylactic MSC administration. We also determined the highest level of CD8 in the CsA+MTX group. The highest level of CD8 in the CsA+MTX group may have an additional vrole in the treatment of GVHD. Recent studies particularly suggested inducible CD8 cells to be useful in suppressing autoimmune reactions, although their function in the alloSCT setting has not been fully explored [28].

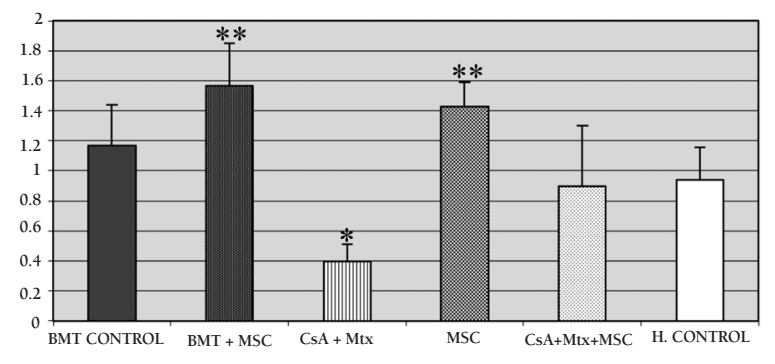

Figure 6. The ratio of CD4/CD8 expression in the study and control groups. The ratio of $\mathrm{CD} 4 / \mathrm{CD} 8$ expression was significantly increased in the MSC groups, but rather decreased in the CsA+MTX group in comparison with the healthy control.

* $\mathrm{p}=0.008$ in comparison with CG-III (healthy control).

** $\mathrm{p}=0.014$ in comparison with CG-III (healthy control).

MSCs may be used for hematopoiesis enhancement, GVHD prophylaxis, and treatment of established severe acute GVHD in allo-HSCT patients. Previous studies have supported the use of MSCs in steroid-refractory GVHD $[11,21,22,23,24,27]$. Intravenous administration of MSCs has been well tolerated [29]. In 1994, Le Blanc et al. reported a case with successful treatment of grade IV acute GVHD of the gut and liver with third-party haploidentical MSCs. They postulated that MSCs have a potent immunosuppressive Veffect in vivo [30]. In 1998, the same researchers published the MSC treatment of steroid-resistant, severe, acute, and chronic GVHD as a phase II study [22]. Herrmann et al. reported a phase I study that was applied to MSC therapy for steroid-refractory acute and chronic GVHD. They administered 2 infusions per patient and the overall response rates for acute GVHD were complete in 7 and partial in 4, with no response in 1 patient. Of the 7 patients who achieved a complete response, 6 were still alive [31].

The combination of cyclosporine and short course of methotrexate is currently considered the standard prophylaxis of GVHD [32]. There is sufficient in vitro evidence to support the use of MSCs in the prevention and treatment of GVHD. However, it has been rarely reported that MSCs were very effective for GVHD prevention in vivo but not in the treatment of GVHD in the xenogeneic model of NOD/SCID mice. In addition, these studies reported no adverse events following the infusion of MSCs, making it possible to use these cells for prevention of acute GVHD $[33,34]$. Tisato et al. designed a study to address these questions in a xenogeneic model testing the ability of umbilical cord blood-derived MSCs to prevent and/or treat GVHD. They reported that MSCs of cord-blood origin are effective in the prevention but not the treatment of GVHD [33]. Another study depicted that MSCs suppress the lymphocyte proliferation in vitro but fail to prevent GVHD in mice (34). However, our study evaluated the clinical potential of MSCs for controlling GVHD in rats. According to our results, prophylactic in vivo use of MSCs was as 


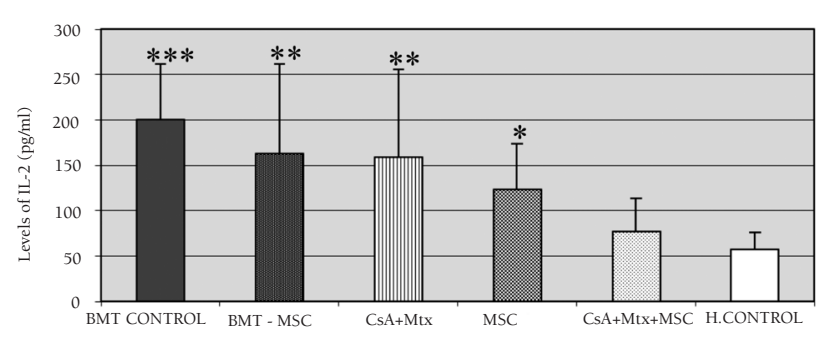

Figure 7. Plasma IL-2 levels $(\mathrm{pg} / \mathrm{mL})$ in the study and control groups. Statistical significance in comparison with the healthy control is shown.

${ }^{*} \mathrm{p}=0.032$ in comparison with CG-III (healthy control).
$* * \mathrm{p}=0.018$ in comparison with CG-III (healthy control).
${ }^{* * *} \mathrm{p}<0.001$ in comparison with CG-III (healthy control).

effective as the standard prophylactic regimen in preventing GVHD. Furthermore, we did not observe any adverse events following the infusion of MSCs. Until recently, there were no published data regarding the preferred dose, timing, and frequency of MSC infusion. However, a randomized controlled phase III trial on the use of MSCs in acute GVHD in humans is currently underway, and the preliminary results are promising [35]. Recently, Kuzmina et al. reported a phase II human study on the use of MSCs for prevention of acute GVHD. This prospective clinical trial was based on random patient allocation to two groups receiving either standard GVHD prophylaxis or standard GVHD prophylaxis combined with MSC infusion. They demonstrated the efficacy of MSCs in GVHD prophylaxis in a limited number of patients with no adverse events directly attributable to administration of MSCs (36). However, our in vivo rat study displayed similar efficacies for both the standard GVHD prophylactic regimen (CsA+MTX) and the prophylactic MSC regimen alone. The immunosuppressive effect of combination of standard GVHD prophylaxis (CsA+MTX) and MSC infusion was also more potent. Although MSC treatment was tolerated well, this potent immunosuppressive effect of the CsA+MTX+MSC combination was associated with increased mortality in our study. The potent immunosuppressive effect of CsA+MTX+MSC combination is to be proven by further studies.

To conclude, clinical use of MSCs in both prophylaxis against and treatment of established GVHD seems to be effective. However, MSC infusion combined with the standard GVHD prophylactic regimen causes stronger immunosuppression, with the potential of resultant early mortality. Clinical use of MSCs in prophylaxis and treatment of GVHD after allo-BMT requires further clinical trials.

\section{Conflict of Interest Statement}

The authors of this paper have no conflicts of interest, including specific financial interests, relationships, and/ or affiliations relevant to the subject matter or materials included.

\section{References}

1. Ferrara JL, Deeg HJ. Graft-versus-host disease. N Engl J Med 1991;324:667-674.

2. Tabbara IA, Zimmerman K, Morgan C, Nahleh Z. Allogeneic hematopoietic stem cell transplantation: complications and results. Arch Intern Med 2002;162:1558-1566.

3. Deeg HJ. How I treat refractory acute GVHD. Blood 2007;109:4119-4126.

4. Kadiyala S, Young RG, Thiede MA, Bruder SP. Culture expanded canine mesenchymal stem cells possess osteochondrogenic potential in vivo and in vitro. Cell Transplant 1997;6,125-134.

5. Pittenger MF, Mackay AM, Beck SC, Jaiswal RK, Douglas R, Mosca JD, Moorman MA, Simonetti DW, Craig S, Marshak DR. Multilineage potential of adult human mesenchymal stem cells. Science 1999;284:143-147.

6. Fibbe WE, Nauta AJ, Roelofs H. Modulation of immune responses by mesenchymal stem cells. Ann NY Acad Sci 2007;1106:272-278.

7. Krampera M, Glennie S, Dyson J, Scott D, Laylor R, Simpson E, Dazzi F. Bone marrow mesenchymal stem cells inhibit the response of naive and memory antigen-specific T cells to their cognate peptide. Blood 2003;101:3722-3729.

8. Glennie S, Soeiro I, Dyson PJ, Lam EW, Dazzi F. Bone marrow mesenchymal stem cells induce division arrest anergy of activated T cells. Blood 2005;105:2821-2827.

9. Jiang XX, Zhang Y, Liu B, Zhang SX, Wu Y, Yu XD, Mao N. Human mesenchymal stem cells inhibit differentiation and function of monocyte-derived dendritic cells. Blood 2005; 105:4120-4126.

10. Aggarwal S, Pittenger MF. Human mesenchymal stem cells modulate allogeneic immune cell responses. Blood 2005;105:1815-1822.

11. Fang B, Song Y, Liao L, Zhang Y, Zhao RC. Favorable response to human adipose tissue-derived mesenchymal stem cells in steroid-refractory acute graft-versus-host disease. Transplant Proc 2007;39:3358-3362.

12. Akpek G. Graft versus host disease (GVHD) an evidence based management guidelines. Turk J Haematol 2003;20:123-142.

13. Ram R, Gafter-Gvili A, Yeshurun M, Paul M, Raanani P, Shpilberg O. Prophylaxis regimens for GVHD: systematic review and meta-analysis. Bone Marrow Transplant 2009;43:643-653.

14. Van Lint MT, Milone G, Leotta S, Uderzo C, Scimè R, Dallorso S, Locasciulli A, Guidi S, Mordini N, Sica S, Cudillo L, Fagioli F, Selleri C, Bruno B, Arcese W, Bacigalupo A. Treatment of acute graft-versus-host disease with prednisolone: significant survival advantage for day +5 responders and no advantage for nonresponders receiving anti-thymocyte globulin. Blood 2006;107:4177-4181. 
15. Couriel DR, Saliba R, Escalón MP, Hsu Y, Ghosh S, Ippoliti C, Hicks K, Donato M, Giralt S, Khouri IF, Hosing C, de Lima MJ, Andersson B, Neumann J, Champlin R. Sirolimus in combination with tacrolimus and corticosteroids for the treatment of resistant chronic graft-versus-host disease. Br J Haematol 2005;130:409-417.

16. Johnston LJ, Brown J, Shizuru JA, Stockerl-Goldstein KE, Stuart MJ, Blume KG, Negrin RS, Chao NJ. Rapamycin (sirolimus) for treatment of chronic graft-versus-host disease. Biol Blood Marrow Transplant 2005;11:47-55.

17. Lopez F, Parker P, Nademanee A, Rodriguez R, Al-Kadhimi Z, Bhatia R, Cohen S, Falk P, Fung H, Kirschbaum M, Krishnan A, Kogut N, Molina A, Nakamura R, O’Donnell M, Popplewell L, Pullarkat V, Rosenthal J, Sahebi F, Smith E, Snyder D, Somlo G, Spielberger R, Stein A, Sweetman R, Zain J, Forman S. Efficacy of mycophenolate mofetil in the treatment of chronic graft-versus-host disease. Biol Blood Marrow Transplant 2005;11:307-313.

18. Kim JG, Sohn SK, Kim DH, Lee NY, Suh JS, Lee KS, Lee KB Different efficacy of mycophenolate mofetil as salvage treatment for acute and chronic GVHD after allogeneic stem cell transplant. Eur J Haematol 2004;73:56-61.

19. Cutler C, Miklos D, Kim HT, Treister N, Woo SB, Bienfang D, Klickstein LB, Levin J, Miller K, Reynolds C, Macdonell R, Pasek M, Lee SJ, Ho V, Soiffer R, Antin JH, Ritz J, Alyea E. Rituximab for steroid-refractory chronic graft-versus-host disease. Blood 2006;108:756-762.

20. Couriel DR, Hosing C, Saliba R, Shpall EJ, Anderlini P, Rhodes B, Smith V, Khouri I, Giralt S, de Lima M, Hsu Y, Ghosh S, Neumann J, Andersson B, Qazilbash M, Hymes S, Kim S, Champlin R, Donato M. Extracorporeal photochemotherapy for the treatment of steroid-resistant chronic GVHD. Blood 2006;107:3074-3080.

21. Ringdén O, Uzunel M, Rasmusson I, Remberger M, Sundberg B, Lönnies H, Marschall HU, Dlugosz A, Szakos A, Hassan Z, Omazic B, Aschan J, Barkholt L, Le Blanc K. Mesenchymal stem cells for treatment of therapy-resistant graft-versushost disease. Transplantation 2006;81:1390-1397.

22. Le Blanc K, Frassoni F, Ball L, Locatelli F, Roelofs H, Lewis I, Lanino E, Sundberg B, Bernardo ME, Remberger M, Dini G, Egeler RM, Bacigalupo A, Fibbe W, Ringdén O; Developmental Committee of the European Group for Blood and Marrow Transplantation. Mesenchymal stem cells for treatment of steroid-resistant, severe, acute graft-versushost disease: a phase II study. Lancet 2008;371:1579-1586.

23. Toubai T, Paczesny S, Shono Y, Tanaka J, Lowler KP, Malter CT, Kasai M, Imamura M. Mesenchymal stem cells for treatment and prevention of graft-versus-host disease after allogeneic hematopoietic cell transplantation. Curr Stem Cell Res Ther 2009;4:252-259.

24. Weng JY, Du X, Geng SX, Peng YW, Wang Z, Lu ZS, Wu SJ, Luo CW, Guo R, Ling W, Deng CX, Liao PJ, Xiang AP. Mesenchymal stem cell as salvage treatment for refractory chronic GVHD. Bone Marrow Transplant 2010;45:17321740 .

25. Lawitschka A, Ball L, Peters C. Nonpharmacologic treatment of chronic graft-versus-host disease in children and adolescents. Biol Blood Marrow Transplant 2012;18(Suppl 1):74-81.
26. Ning HM, Jin JG, Hu JW, Feng K, Chen H. Effect of human bone marrow mesenchymal stem cell on allogeneic $\mathrm{T}$ lymphocyte phenotype in vitro. Zhongguo Shi Yan Xue Ye Xue Za Zhi 2005;13:43-49.

27. Tian Y, Deng YB, Huang YJ, Wang Y. Bone marrow-derived mesenchymal stem cells decrease acute graft-versushost disease after allogeneic hematopoietic stem cells transplantation. Immunol Invest 2008;37:29-42.

28. Avivi I, Stroopinsky D, Rowe JM, Katz T. A subset of CD8+ $\mathrm{T}$ cells acquiring selective suppressive properties may play a role in GvHD management. Transpl Immunol 2013;28:5761.

29. Lazarus HM, Koc ON, Devine SM, Curtin P, Maziarz RT, Holland HK, Shpall EJ, McCarthy P, Atkinson K, Cooper BW, Gerson SL, Laughlin MJ, Loberiza FR Jr, Moseley AB, Bacigalupo A. Cotransplantation of HLA-identical sibling culture-expanded mesenchymal stem cells and hematopoietic stem cells in hematologic malignancy patients. Biol Blood Marrow Transplant 2005;11:389-398.

30. Le Blanc K, Rasmusson I, Sundberg B, Götherström C, Hassan M, Uzunel M, Ringdén O. Treatment of severe acute graft-versus-host disease with third party haploidentical mesenchymal stem cells. Lancet 2004;363:1439-1441.

31. Herrmann R, Sturm M, Shaw K, Purtill D, Cooney J, Wright M, Phillips M, Cannell P. Mesenchymal stromal cell therapy for steroid-refractory acute and chronic graft versus host disease: a phase 1 study. Int J Hematol 2012;95:182-188.

32. Ram R, Gafter-Gvili A, Yeshurun M, Paul M, Raanani P, Shpilberg O. Prophylaxis regimens for GVHD: systematic review and meta-analysis. Bone Marrow Transplant 2009;43:643-653.

33. Tisato V, Naresh K, Girdlestone J, Navarrete C, Dazzi F. Mesenchymal stem cells of cord blood origin are effective at preventing but not treating graft-versus-host disease. Leukemia 2007;21:1992-1999.

34. Sudres M, Norol F, Trenado A, Grégoire S, Charlotte F, Levacher B, Lataillade JJ, Bourin P, Holy X, Vernant JP, Klatzmann D, Cohen JL. Bone marrow mesenchymal stem cells suppress lymphocyte proliferation in vitro but fail to prevent graft-versus-host disease in mice. J Immunol 2006;176:7761-7767.

35. Jones BJ, McTaggart SJ. Immunosuppression by mesenchymal stromal cells: from culture to clinic. Exp Hematol 2008;36:733-741.

36. Kuzmina LA, Petinati NA, Parovichnikova EN, Lubimova LS, Gribanova EO, Gaponova TV, Shipounova IN, Zhironkina OA, Bigildeev AE, Svinareva DA, Drize NJ, Savchenko VG. Multipotent Mesenchymal Stromal Cells for the Prophylaxis of Acute Graft-versus-Host Disease-A Phase II Study. Stem Cells Int 2012: 968213. 